\title{
Spatial Assessment And Source Identification Of Heavy Metals Pollution In Surface Water Using Several Chemometric Techniques
}

\author{
Azimah Ismail ${ }^{1}$, Mohd Ekhwan Toriman ${ }^{1}$, Hafizan Juahir ${ }^{1}$, Sharifuddin Md Zain ${ }^{3}$, Nur Liyana Abdul Habir ${ }^{1}$, \\ Ananthy Retnam ${ }^{2}$, Mohd Khairul Amri Kamaruddin ${ }^{1}$, Roslan Umar ${ }^{1}$ and Azman Azid ${ }^{1}$ \\ ${ }^{1}$ East Coast Environmental Research Institute (ESERI), Universiti Sultan Zainal Abidin, Gong Badak \\ Campus, 21300 Kuala Terengganu, Malaysia. \\ ${ }^{2}$ Environmental Health Division, Department of Chemistry Malaysia, Ministry of Science, Technology \\ and Inovation, Jalan Sultan, Petaling Jaya, Selangor, Malaysia. \\ ${ }^{3}$ Chemistry Department, University of Malaya, 50603 Kuala Lumpur, Malaysia
}

\section{Capsule}

The monitoring of spatial variation and source of heavy metals pollution at the northern and southern regions of the Straits of Malacca, Malaysia, using chemometric analysis.

\begin{abstract}
This study presents the determination of the spatial variation and source identification of heavy metals pollution in surface water along the Straits of Malacca using several chemometric techniques. Clustering and discrimination of heavy metal compounds in surface water into two groups (northern and southern regions) are observed according to level of concentrations via the application of chemometric techniques. Principal component analysis (PCA) demonstrates that $\mathrm{Cu}$ and $\mathrm{Cr}$ dominate the source apportionment in northern region with a total variance of $57.62 \%$ and is identified with mining and shipping activities. These are the major contamination contributors in the Straits. Landbased pollution originating from vehicular emission with a total variance of $59.43 \%$ is attributed to the high level of $\mathrm{Pb}$ concentration in the southern region. The results revealed that one state representing each cluster (northern and southern regions) is significant as the main location for investigating heavy metals concentration in the Straits of Malacca which would save monitoring cost and time.
\end{abstract}

KEYWORDS : heavy metals; Straits of Malacca; principal component analysis; chemometric; source apportionment

\section{INTRODUCTION}

The increase in urbanization has led to an increase of pollutant discharge points into the Straits of Malacca, from both land-based and sea-based sources in a bulk-scale (Abdullah et al., 1999). Anthropogenic inputs contribute to the presence of pollutants that exhibit high toxicity into the marine ecological environment. The potential accumulation of waterborne heavy metals particularly Cadmium, Cuprum, Lead and Arsenic may have potential threat to the natural environmental marine communities and aggravate human health (Zakaria and Takada, 2007). In Malaysia, most pollutants are generated from industrial activities, intentional discharge from operation of vessels at ports, gas and crude oil platforms, petroleum refining and fertilizer manufacturing.

Corresponding author Tel: +609-6688489

Email address : ekhwan@unisza.edu.my 
According to Department of Environment (DOE) 2008, extensive changes in landuse and industrialization have cause proliferation of heavy metal wastes like cadmium $(\mathrm{Cd})$, copper $(\mathrm{Cu})$, lead $(\mathrm{Pb})$ and mercury $(\mathrm{Hg})$, specifically in the littoral states; Pulau Pinang, Perak, Selangor and Malacca into the Malacca Straits. Manufacturing sectors contribute a wide variety heavy metal pollutants in the coastlines of Western Peninsular Malaysia (Thia-Eng et al., 2000). Persistent organic pollutants (POPs) from the petroleum spills or tanker wreckage such as nickel and copper have environmentally contaminated and polluted the seawater surface and sediment, leading to the accumulation of heavy metals in aquatic systems (Santos-Echeandia et al., 2009). In addition, marine estuarine environment will be significantly impacted from accumulation of toxic substances and oil spill (Sun et al., 2012). Metal concentrations in sediment cores for example, were detected considerably higher in 1993, along the east-west axis of the Straits of Johore between Singapore and Malaysia compared to other years (Wood et al., 1997).

Heavy metals and metallic chemical elements (such as hydrogen, lithium,sodium, potassium and rubidium), highly dense and toxic, non-biodegradable substances are transported into marine ecological environment through storm runoff, and subsequently result in bioaccumulation in aquatic living organisms over a long period, dangerously affecting human health via consumption of food from a variety of aquatic life forms (Irwandi, 2009; Nazli et. al., 2010). Agricultural sector is another endocrine contributor of heavy metals in the environment, sourced from fertilizers, pesticides and herbicides. Research in marine environmental system relating to ecotoxicology stated that mercury, cadmium, copper and zinc are the most dangerous heavy metals in the environment (Galovanova et al., 2008). Studies on identification and apportionment of heavy metals in the environment have been conducted worldwide. One example is the study on the accumulation of mercury, chromium, lead, arsenic and cadmium in European catfish into human body via food webs, skin and all important organs on aquatic ecosystems, leading potential deleterious effects to humans (Squadrone et al., 2013). Cadmium and lead have been traced in living organisms such as littoral shore mollusk (Thais species), rock oyster and mangrove plants sediment in the West Coast of Peninsular Malaysia, along the Straits of Malacca (Shazili et. al., 2006; Nazli et. al., 2010). It is unfortunate that economic development often lead to marine pollution by waste discharges from agricultural activities such as pesticide and fertilizers, industries such as heavy metals and hydrocarbon, sewage effluents and shipping such as an oil spillage, which consist of harmful substances that can affect human health and other organism, hence can change the quality of the seawater.

Chemometric techniques allow the study of statistical-correlation in terms of faunal structure, physicochemical characteristics and toxicological data, are found to be significant in analyzing dataset from laboratory analyses. The techniques provide the most appropriate tools for a meaningful data reduction and interpretation (Satheeshkumar, 2011). Moreover, the application of unbiased and precise methods viz. principal component analysis (PCA), cluster analysis (CA) and discriminant analysis (DA) and multi linear regression offers better insight and in-depth interpretation of heavy metals in water surface. Kannel (2007) had suggested the application of a variety of methods for multivariate analyses to reduce the complexity of large amounts of data and provide better data interpretation. CA, as an unsupervised pattern recognition technique functions to group variables and observations. It is able to establish heavy metals signatures and evaluate potential sources of pollutant variables (Han, Y. et al., 2006). Further, CA helps in the identification of heavy metals fingerprint and its origin and variations between sampling sites along the Straits of Malacca. Commonly, the application of CA is to group the sampling sites of heavy metals having similar characteristics and to identify variations between sampling sites. Results obtained from the clustering enables data interpretation and pattern recognition of heavy metals. DA can be used to support CA as a pattern recognition (Juahir et al., 2011) and data classification technique with prior knowledge of the objects of the particular sampling sites(Singh et al., 2004). PCA is commonly applied as a data reduction technique that reduces the large amounts of variables into smaller set of components that can be easily interpreted (Zhou et al., 2007). The application of PCA provides important information that describes the whole data set without losing any of the original information. PCA is usually employed to detect correlation between heavy metal variables for source identification in water surface. 
This study aims to identify heavy metals pollution distribution and the most significant sources via a comprehensive application of multivariate analyses, on data sets obtained from the Department of Environment (DOE). Datasets consist of a five-year period (2006-2010) marine water heavy metals concentrations. It is desired that results obtained from this study will enable the optimization of the monitoring program along the Straits of Malacca as a pollution control mechanism and source identification of heavy metals pollutants. Furthermore, the involvement of environmental forensics has the potential to assist relevant enforcement agencies to bring the polluters to justice and all related issues concerning pollution of heavy metals can be addressed more fruitfully.

\section{METHODOLOGY}

\subsection{Study Areas}

This study was conducted along the Straits of Malacca, located at the West Coast of Peninsular Malaysia. The study area covers the coordinates ' $\mathrm{N} 06^{\circ} 20^{\prime}$ to $\mathrm{N} 01^{\circ} 41^{\prime}$ and $\mathrm{E} 100^{\circ} 09^{\prime}$ to $\mathrm{E} 103^{\circ} 05^{\prime}$ ', along the coastline areas of Perlis to Johor as shown in Figure 1. The Straits of Malacca separates the Peninsular Malaysia and Sumatra of Indonesia. It forms a funnel-shaped waterway and narrows down towards the south. It ends in the area between Tanjung Piai, Johor, Malaysia and Pulau Karimun Kecil in Indonesia (Rusli, 2012). The Malacca Straits has a tropical climate, which consists of wet and dry season and influenced by the northeast monsoon, bringing rain from December to February and dry season from June to August due to south-west monsoon. During the inter-monsoon period from March to May, and September to November, the weather is not stable and unpredictable. (Chua et al., 2000).

The West Coast of Peninsular Malaysia is dominated by coastal plains and basin formed by alluvial deposits. The Malacca Straits is the busiest international shipping route in the world for crude oil trading from Middle East to Asian countries like China and South Korea (Zakaria and Takada, 2007). Since the last decade, states of Pulau Pinang and Johor are known to have robust urbanization activities. Both states are on a fast industrialization track, constantly upgrading their maritime shipping industries. Although the state of Johor is experiencing tremendous urbanization, the state remains as the most agricultural state in the West Coast of Malaysia, particularly palm oil and coconut plantations (Liow et al., 2001). Perak, which is also a state along the straits, has the largest tin extraction and mining activities in Malaysia.

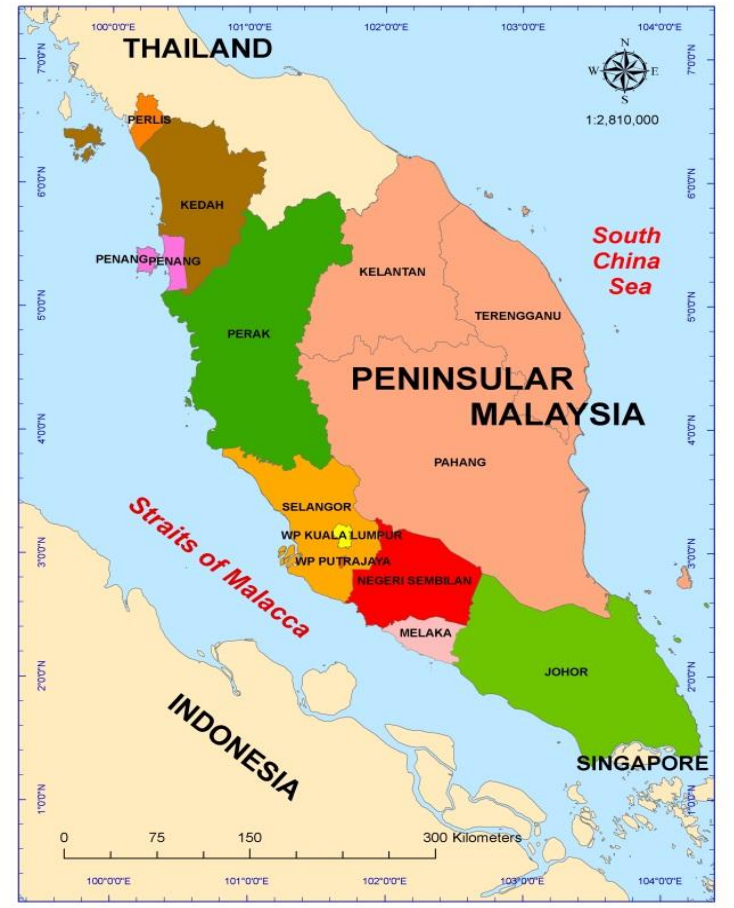

Figure 1: Map for the sampling and monitoring locations in states along the Straits of Malacca 


\subsection{Monitoring parameters and pre-treatment data}

Datasets of marine water from eight monitoring station in the littoral states along the Straits of Malacca consist of nine parameters including six heavy metals obtained from the Department of Environment Malaysia (DOE) from 2006 until 2010. Samplings frequencies yearly are between two to nine times according to the areas. The industrialized and fully developed states such as Pulau Pinang require more than two sampling frequencies, while only two sampling frequencies were conducted in the least developed state like Perlis. For the analyses of heavy metals, we have focused on six parameters viz. arsenic $(\mathrm{As})$, cadmium $(\mathrm{Cd})$, chromium $(\mathrm{Cr})$, copper $(\mathrm{Cu})$, lead $(\mathrm{Pb})$ and mercury $(\mathrm{Hg})$. Prior to a comprehensive chemometric statistical analyses, an appropriate data checking viz. normal distribution and data transformation for each variable using a normality tests such as Shapiro-Wilk, Anderson-Darling, Liliforths and Jarque-Bera, with 95\% confidence level is important. Chemometric techniques are sensitive to anomalies in data distribution especially when the raw dataset are not normally distributed $(\mathrm{p}<0.05)$. Some of the data were below detectable limits and are non-numerical. Consequently, the dataset were transformed into a numerical form to ease the analyses (Junninen et al., 2004) using the following equations (Eq. 1 and Eq.2):

$\mathrm{Y}=\mathrm{X}-\mathrm{X} / 2 \ldots \ldots \ldots \ldots$ if it is noted $<\mathrm{X} \quad$ (Eq. 1)

$\mathrm{Y}=\mathrm{X} / 2+\mathrm{X}$............. if it is noted $>\mathrm{X} \quad$ (Eq. 2 )

The data were transformed and arranged using log-transformation and z-scale standardized (mean $=0$, standard deviation $=1$ ) to ensure that each variables having the same influence in the analysis (Zhou et al., 2007; Satheeshkumar, 2010). After the data conversion, the dataset were formed into a single matrix of heavy metal variables vs. sampling points (littoral states), forming a [6 x 10] data matrix. The Non-detectable data are replaced by one half of the detection limit value (Retnam et al., 2013).

The Z-scale transformation was applied using the following equation (Eq.3):

$$
\mathrm{Z}=\frac{x-x^{\prime}}{\sigma} \quad \text { (Eq. 3) }
$$

where $\mathrm{x}$ is the original value of a measured parameter, $\mathrm{Z}$ is the standardized value, $\mathrm{x}$ ' the average value of variables and $\sigma$ is the standard deviation (Kannel et al., 2007).

where, $\mathrm{Y}$ represents the estimated observation and $\mathrm{X}$ is the actual observation. The descriptive statistics, mean and standard deviation (S.D) for a five-year period dataset of heavy metals along the Straits of Malacca are summarized in Table 1. 
Table 1: Mean and Standard Deviation values of Heavy Metals in water surface along Straits of Malacca from 2006 to 2010.

\begin{tabular}{|c|c|c|c|c|c|c|c|c|c|c|}
\hline \multirow[b]{2}{*}{ State } & \multirow[b]{2}{*}{ Sampling Station } & \multirow[b]{2}{*}{ Longitude } & \multirow[b]{2}{*}{ Latitude } & \multirow[b]{2}{*}{ Statistics } & \multicolumn{6}{|c|}{ Parameters } \\
\hline & & & & & $\begin{array}{c}\text { As } \\
(\mathrm{mg} / \mathrm{l})\end{array}$ & $\begin{array}{c}\mathrm{Cr} \\
(\mathrm{mg} / \mathrm{l})\end{array}$ & $\begin{array}{c}\mathrm{Cu} \\
(\mathrm{mg} / \mathrm{l})\end{array}$ & $\begin{array}{c}\mathrm{Pb} \\
(\mathrm{mg} / \mathrm{l})\end{array}$ & $\begin{array}{c}\mathrm{Hg} \\
(\mathrm{mg} / \mathrm{l})\end{array}$ & $\begin{array}{c}\mathrm{Cd} \\
(\mathrm{mg} / \mathrm{l})\end{array}$ \\
\hline \multirow[b]{2}{*}{ Perlis } & Kuala Sg, Baru & $\mathrm{N} \mathrm{06}^{\circ} 19.908^{\prime}$ & E $100^{\circ} 09.333^{\prime}$ & Mean & 0.007 & 0.100 & 0.033 & 0.106 & 0.002 & 0.043 \\
\hline & Kuala Sg. Perlis & $\mathrm{N} 06^{\circ} 23.983^{\prime}$ & E $100^{\circ} 07.580^{\prime}$ & SD & 0.004 & 0.102 & 0.024 & 0.054 & 0.002 & 0.277 \\
\hline \multirow{4}{*}{ Kedah } & Pantai Kok & ${\mathrm{N} 06^{\circ} 22.020^{\prime}}^{\prime}$ & E $099^{\circ} 40.728^{\prime}$ & \multirow{2}{*}{ Mean } & \multirow{2}{*}{0.003} & \multirow[t]{2}{*}{0.132} & \multirow{2}{*}{0.045} & \multirow[t]{2}{*}{0.100} & \multirow{2}{*}{0.002} & \multirow[t]{2}{*}{0.005} \\
\hline & Pantai Kuah & $\mathrm{N} 06^{\circ} 19.069^{\prime}$ & E $099^{\circ} 51.075^{\prime}$ & & & & & & & \\
\hline & Kuala Kedah & N $6^{\circ} 07^{\prime} 09^{\prime}$ & E $100^{\circ} 16^{\prime} 54^{\prime}$ & \multirow[b]{2}{*}{ SD } & \multirow{2}{*}{0.002} & \multirow{2}{*}{0.131} & \multirow{2}{*}{0.035} & \multirow{2}{*}{0.000} & \multirow{2}{*}{0.003} & \multirow{2}{*}{0.001} \\
\hline & Pantai Merdeka & N $5^{\circ} 38^{\prime} 12^{\prime}$ & $\mathrm{E} 100^{\circ} 23^{\prime} 22^{\prime}$ & & & & & & & \\
\hline \multirow{3}{*}{ Pulau Pinang } & $\begin{array}{l}\text { Kuala Sg. Juru } \\
\text { Kuala Sg. Perai }\end{array}$ & $\begin{array}{l}\mathrm{N} 05^{\circ} 20^{\prime} 20.0^{\prime \prime} \\
\mathrm{N} 05^{\circ} 23^{\prime} 00.0^{\prime \prime}\end{array}$ & $\begin{array}{l}\text { E } 100^{\circ} 24^{\prime} 20.0^{\prime \prime} \\
\text { E } 100^{\circ} 22^{\prime} 00.0^{\prime \prime}\end{array}$ & Mean & 0.005 & 0.167 & 0.058 & 0.125 & 0.004 & 0.015 \\
\hline & Bayan Lepas I & $\mathrm{N} 05^{\circ} 20^{\prime} 00.0^{\prime \prime}$ & E $100^{\circ} 18^{\prime} 45.0^{\prime \prime}$ & & & & & & & \\
\hline & Pulau Aman & N $05^{\circ} 15^{\prime} 50.0^{\prime \prime}$ & E $100^{\circ} 23^{\prime} 35.0^{\prime \prime}$ & SD & 0.004 & 0.159 & 0.027 & 0.090 & 0.007 & 0.017 \\
\hline & $\begin{array}{l}\text { Kuala Sg. Manjung } \\
\text { Kuala Sg. Perak }\end{array}$ & $\begin{array}{l}\mathrm{N} 04^{\mathrm{O}} 14^{\prime} 09^{\prime \prime} \\
\mathrm{N} 03^{0} 59^{\prime} 03.5^{\prime \prime}\end{array}$ & $\begin{array}{l}\text { E } 100^{\circ} 39^{\prime} 57^{\prime \prime} \\
\text { Е } 100^{\circ} 48^{\prime} 58^{\prime \prime}\end{array}$ & Mean & 0.001 & 0.005 & 0.030 & 0.160 & 0.001 & 0.001 \\
\hline Perak & Pantai Pasir Bogak & $\mathrm{N} 04^{0} 12^{\prime} 58.0^{\prime \prime}$ & E $100^{\circ} 37^{\prime} 55.0^{\prime \prime}$ & SD & 0002 & 0021 & 0033 & 0169 & 0001 & 0007 \\
\hline & Pantai Teluk Batik & $\mathrm{N} 04^{0} 11^{\prime} 14.0^{\prime}$ & E $100^{\circ} 36^{\prime} 33.1^{\prime \prime}$ & SD & 0.002 & 0.021 & 0.033 & 0.169 & 0.001 & 0.001 \\
\hline & Pantai Morib & ${\mathrm{N} 02^{\circ} 48.25^{\prime}}^{\prime}$ & E $101^{\circ} 24.15^{\prime}$ & Mean & 0.004 & 0.003 & 0.002 & 0.004 & 0.001 & 0.001 \\
\hline Selangor & Kuala Sg. Sepang & $\mathrm{N} 02^{\circ} 35.35^{\prime}$ & E $101^{\circ} 42.56^{\prime}$ & & & & & & & \\
\hline & $\begin{array}{l}\text { Kuala Sg. Langat } \\
\text { Kuala Sg. Buloh }\end{array}$ & $\begin{array}{l}\mathrm{N} 02^{\circ} 48.25^{\prime} \\
\mathrm{N} 03^{\circ} 10.00^{\prime}\end{array}$ & $\begin{array}{l}\text { E } 101^{\circ} 24.15^{\prime} \\
\text { E } 101^{\circ} 15.50\end{array}$ & SD & 0.004 & 0.009 & 0.004 & 0.005 & 0.001 & 0.000 \\
\hline & Kuala Sg. Linggi & $\mathrm{N} 02^{\circ} 23.20^{\prime}$ & E $101^{\circ} 58.19^{\prime}$ & & & & & & & \\
\hline N Sembilan & Bagan Pinang & $\mathrm{N} 02^{\circ} 30.31^{\prime}$ & E $101^{\circ} 49.44^{\prime}$ & Mean & 0.003 & 0.008 & 0.001 & 0.007 & 0.002 & 0.002 \\
\hline N. sembilan & Teluk Sinting & $\mathrm{N} 02^{\circ} 24.57^{\prime}$ & $\mathrm{E} 101^{\circ} 56.31^{\prime}$ & SD & & & & & & \\
\hline & PD Batu 10 & $\mathrm{~N} 02^{\circ} 24.58^{\prime}$ & E $101^{\circ} 51.23^{\prime}$ & SD & 0.002 & 0.0038 & 0.001 & 0.010 & 0.003 & 0.004 \\
\hline & Kula Sg. Kesang & 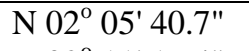 & E $102^{\circ} 29^{\prime} 12.3^{\prime \prime}$ & Mean & 0.005 & 0.003 & 0.004 & 0.024 & 0.001 & 0.003 \\
\hline Malacca & Kuala Sg. Melaka & $\mathrm{N} 02^{\circ} 11^{\prime} 16.4 "$ & E $102^{\circ} 14^{\prime} 39.2^{\prime \prime}$ & & & & & & & \\
\hline & $\begin{array}{l}\text { Kuala Sg. Merlımau } \\
\text { Pantai Kundur }\end{array}$ & $\begin{array}{l}\mathrm{N} 02^{\circ} 07^{\prime} 36.3^{\prime \prime} \\
\mathrm{N} 02^{\circ} 13^{\prime} 46.6^{\prime \prime}\end{array}$ & $\begin{array}{l}\text { Е } 102^{\circ} 24^{\prime} 50.6^{\prime \prime} \\
\text { Е } 102^{\circ} 08^{\prime} 52.9^{\prime \prime}\end{array}$ & $\mathrm{SD}$ & 0.000 & 0.000 & 0.003 & 0.019 & 0.000 & 0.000 \\
\hline & Pantai Kukup & $\mathrm{N} \mathrm{01}^{\circ} 19^{\prime} 30.0^{\prime \prime}$ & E $103^{\circ} 26^{\prime} 29.0^{\prime \prime}$ & & & & & & & \\
\hline Johor & Pantai Sg. Lurus & N 014 $43^{\prime} 14.0^{\prime \prime}$ & E $103^{\circ} 01^{\prime} 43.0^{\prime \prime}$ & Mean & 0.004 & 0.050 & 0.046 & 0.001 & 0.001 & 0.034 \\
\hline Johor & Punggur & N 01 41' 04.9" & E $103^{\circ} 05^{\prime} 54.0^{\prime \prime}$ & SD & 0005 & 0000 & 0036 & 0000 & 0001 & 0006 \\
\hline & Kuala Sg. Muar & $\mathrm{N} 02^{\circ} 02^{\prime} 54.0^{\prime \prime}$ & E $102^{\circ} 33^{\prime} 11.0^{\prime \prime}$ & $\mathrm{SD}$ & 0.005 & 0.000 & 0.050 & 0.000 & 0.001 & 0.000 \\
\hline
\end{tabular}

Note: Zero value means below detection limit. 


\subsection{Statistical analysis: Chemometric methods}

Several chemometric techniques were applied to assess heavy metal concentrations and identify the source of these pollutants. A comprehensive analysis was performed using XLSTAT 2007. XLSTAT 2007 is a Microsoft statistical add-in, offering greatly user-friendly, highly-efficient statistical analysis and multivariate analysis package (Hafizan et al., 2010).

\subsubsection{Cluster Analysis (CA)}

The CA was performed where similar variables are divided into similar group having similar characteristics to other group without prior assumptions, clustering variables into group classes known as clusters (Zhou et al., 2007; Cai et al., 2012). Hierarchical agglomerative CA (HACA) was performed according to standardized data using Ward's method with squared Euclidean distances for the determination of the spatial variations of heavy metals in marine water. Results of CA are illustrated as a dendrogram that indicates the cluster and their homogeneity (Juahir et al., 2011). The linkage distance is reported as $\mathrm{D}_{\text {link }} / \mathrm{D}_{\text {max }}$, a quotient between the linkage distances divided by maximal distance which is represented as the y-axis (Dominick et al., 2012).

\subsubsection{Discriminant Analysis (DA)}

DA was applied to validate the reliable classification of observations in CA analyses based on a set of variables known as predictors. DA determines the heavy metal variables and discriminate them into two or more groups (clusters) (Zhou et al., 2007; Kannel et. al., 2007; Blundell, A.B. et al., 2009; Juahir et al., 2011; Retnam et al., 2013; Fermo, P. et al., 2013 ). Unlike CA, DA was applied on the original dataset and has similar discriminant ability towards the original data set with or without standardization (Kannel et al. 2007) in constructing the Discriminant Factor (DF). Thus, standardization to the original data set was not necessarily significant and the DA was performed by following function (Eq.4):

$f(G i)=k i+\sum_{j=1}^{n} w i j \cdot p i j \quad$ (Kannel et al., 2007) (Eq. 4)

where $i$ is the number of groups $(G), k_{i}$ is the constant inherent to each group, $n$ is the number of parameters used to classify a set of data into given group and $\mathrm{w}_{\mathrm{ij}}$ is the weight coefficient which was assigned by DA to a given parameter ( $\mathrm{p}_{\mathrm{ij}}$ ) (Zhou et al., 2007).

DA was applied in this study to construct Discriminant Factors (DF) according to three modes viz. standard mode, forward stepwise mode and backward stepwise mode. In the forward stepwise mode, the most significant heavy metal variables to the least significant variables were added one-byone until no significant changes are obtained/observed. However, in the backward stepwise mode, the variables of heavy metals were removed one-by-one, starting with the least significant variables until no significant changes area obtained. In this study, DA was performed on heavy metal raw data matrix with the column consisting of all the heavy metal concentrations as independent variables and the row consisting the group from CA as dependent variables.

\subsubsection{Principal component analysis (PCA)}

The PCA method is used to identify the most significant variables which determine the spatial and temporal variations of the dataset set by 'excluding' the less significant parameters with minimum loss of important original information (Kannel et al., 2007). PCA constructs latent variables (scores) which are the linear combinations of the original data variables of heavy metal concentrations. In PC analyses for heavy metals, latent variables with eigenvalue $>1.0$ are considered significant. PCA can be expressed with the following equation:-

$$
z_{i j}=a_{i 1} X_{1 j}+a_{i 2} X_{2 j}+a_{i 3} X_{3 j}+a_{i m} X_{m j}
$$


where, $\mathrm{z}$ is the component score, $\mathrm{a}$ is the component loading, $\mathrm{x}$ is the measured original variables, $\mathrm{i}$ is the component number and $\mathrm{m}$ represents the number of the original variables. The loadings ascertain the significance of the heavy metal parameters for each component.

\section{RESULTS AND DISCUSSION}

\subsection{Descriptive statistics}

From the original data, variation was clearly observed for the concentrations of heavy metals in water surface along the Straits of Malacca. The concentrations of heavy metals are significantly different for each sampling sites. Figure 2 shows the spatial distribution of heavy metals in marine water along the Straits of Malacca. The lowest and highest concentrations of As $(0.0025 \mathrm{mg} / \mathrm{l})$ and $\mathrm{Pb}$ $\mathrm{Pb}(0.160 \mathrm{mg} / \mathrm{l})$ are observed in the State of Johor. The highest concentrations of $\mathrm{Cd}(0.050 \mathrm{mg} / \mathrm{l}$ and $0.045 \mathrm{mg} / \mathrm{l})$ are observed in Perlis and Johor and the concentration of $\mathrm{Cr}(0.150 \mathrm{mg} / \mathrm{l})$ is highest in the State of Kedah followed by Perlis.

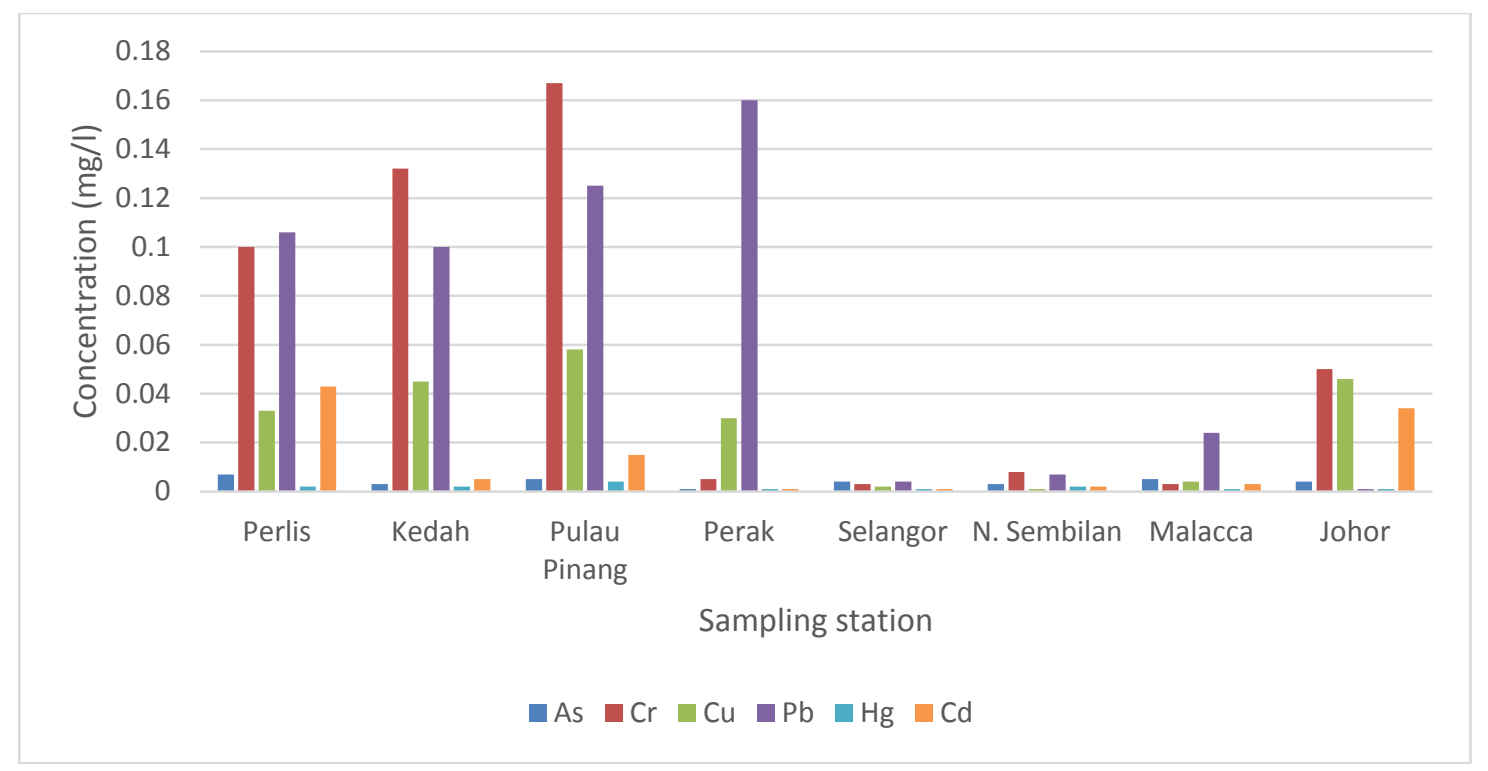

Figure 2: Spatial distribution of heavy metals in marine water along the Straits of Malacca

The datasets are compared to the Interim Marine Water Quality Standards, which had been derived from the Department of Environment Malaysia (DOE). From the comparison, the heavy metals are in trace levels and do not exceed the standards. Clearly, the heavy metals have been diluted in flowing from the source-point towards the Straits of Malacca. The comparison of variables and the standards is presented in Table 2. 
Table 2: Comparison of Heavy Metal Concentrations with the Interim Marine Water Quality Standards.

\begin{tabular}{lccc}
\hline \multicolumn{1}{c}{ Parameters } & Unit & Concentration & Standard \\
\hline Arsenic $(\mathrm{As})$ & $(\mathrm{mg} / \mathrm{l})$ & 0.004 & 0.100 \\
Chromium $(\mathrm{Cr})$ & $(\mathrm{mg} / \mathrm{l})$ & 0.077 & 0.500 \\
Copper $(\mathrm{Cu})$ & $(\mathrm{mg} / \mathrm{l})$ & 0.024 & 0.100 \\
Lead $(\mathrm{Pb})$ & $(\mathrm{mg} / \mathrm{l})$ & 0.069 & 0.100 \\
Mercury $(\mathrm{Hg})$ & $(\mathrm{mg} / \mathrm{l})$ & 0.001 & 0.001 \\
Cadmium $(\mathrm{Cd})$ & $(\mathrm{mg} / \mathrm{l})$ & 0.013 & 0.100 \\
\hline
\end{tabular}

\subsection{Spatial classification of heavy metals in marine water along the Straits of Malacca}

To classify the heavy metals spatially, CA was applied to the trace metal data of the marine water according to the homogeneity of the observations. Results from HACA indicate that the sampling sites have similar heavy metal contribution towards the Water Quality Index (WQI) and are clustered together. The output demonstrates that the sampling sites of heavy metals are grouped into two distinctive clusters (northern and southern regions) in the hierarchical dendrogram at $\left(\mathrm{D}_{\text {link }} / \mathrm{D}_{\max }\right) \times 100$ $<40$ (Figure 3.0 (a)).

In the northern region, there are four states that are clustered together viz. Perlis, Kedah, Pulau Pinang, and Perak, while for the southern region the states are Selangor, N. Sembilan, Malacca and Johor. Based on the cluster obtained from CA, four states are observed in each region by employing the homogeneity/similarities characteristic of their land use activities and similar source of contamination. Each of the four states in every region is clustered together according to the severity level of pollutant sources with regards to sampling station location and are represented as LPS (lowpoint source), MPS (medium-point source) and HPS (high-point source). In the northern region, the activities are related mainly to industry and mining, whereas activities in the southern region are mainly shipping and oil refineries. The clustering process indicates that one state from each region is sufficient in representing the heavy metals contamination of marine systems in surface water along the Straits of Malacca. In addition, re-assessment of pollutant sources in surface water needs to be carried out regularly to take into consideration changes in land use activities that may contribute to marine pollution within the cluster. From the result of this study, CA can be seen as a highly effective statistical technique for clustering the regions of pollution, and its results can be applied to improve sampling strategies and monitoring plans.

\subsection{Spatial variation of heavy metals contamination along the Straits of Malacca}

To explore the spatial similarity of trace metal contamination/concentration in the Straits of Malacca, DA was performed on the dataset after clustering the sampling sites into two groups (hierarchical clusters) which are obtained through CA. DA was performed on the original data set to test the significance of the cluster analysis and to ascertain the significance of the parameters of the clusters. The two clusters (northern and southern regions) were treated as dependent variables and the heavy metals as independent variables.

Validations of the results were carried out on the discriminating variables where the dataset were subjected to three modes, standard, forward stepwise and backward stepwise. With the standard mode DA, the sampling sites were discriminated to a $93.30 \%$ classification matrix accuracy, performed by 
discriminant function (DF's) with six discriminant variables. In the forward mode, the classification matrix has an accuracy of $92.86 \%$, while backward stepwise has an accuracy of $93.08 \%$ (Table 3 (a) and (b)). The findings indicate that the spatial distribution clustering obtained through CA is further confirmed. Forward stepwise DA reveals that $\mathrm{Pb}, \mathrm{Cr}$ and $\mathrm{Cu}$ are the three most significant variables in the spatial discrimination of heavy metals for both clusters with an accuracy of $92.86 \%$. On the other hand, backward stepwise mode discriminant analysis demonstrates that $\mathrm{Pb}, \mathrm{Cr}, \mathrm{Hg}$ and $\mathrm{Cu}$ are the four most significant variables contributing to the high spatial variation. Box and whisker plots of the three discriminating heavy metal variables identified via forward stepwise shows their variation at the two sampling sites (northern and southern regions) (Figure 3 (b) and (c)).

Output from DA stepwise mode clearly shows that this technique is a useful tool to identify the discriminating variables in the spatial variance of the heavy metals. The three most significant variables that are determined via the forward stepwise DA constitute the most optimum number of heavy metals required for further consideration in future spatial monitoring of contaminants along the Straits of Malacca.

Table 3: (a) DA Classification matrix for spatial variation

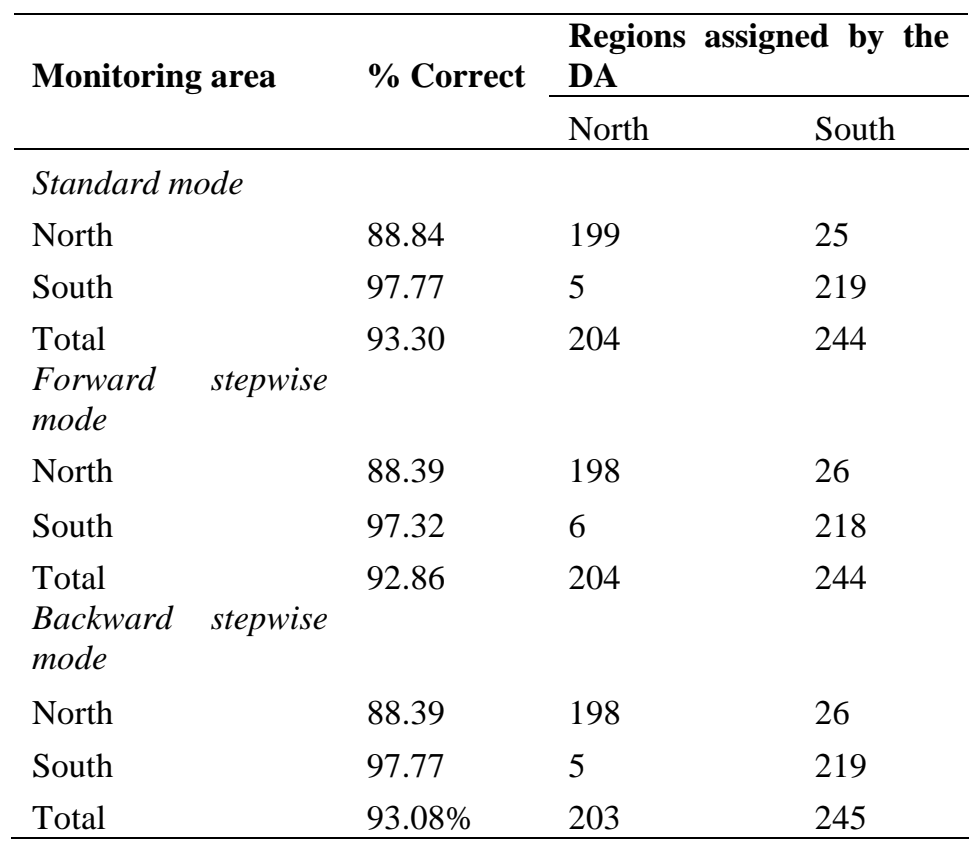

(b) Classification Function Coefficients for DA of spatial variation.

\begin{tabular}{|c|c|c|c|c|c|c|}
\hline \multirow[t]{2}{*}{ Parameters } & \multicolumn{2}{|c|}{ Standard Mode } & $\begin{array}{l}\text { Forward } \\
\text { Mode }\end{array}$ & Stepwise & $\begin{array}{l}\text { Backward } \\
\text { Mode }\end{array}$ & Stepwise \\
\hline & North & South & North & South & North & South \\
\hline As $(\mathrm{mg} / \mathrm{l})$ & 282.632 & 289.895 & & & & \\
\hline $\mathrm{Cr}(\mathrm{mg} / \mathrm{l})$ & 11.229 & 0.679 & 11.358 & 0.906 & 11.448 & 0.952 \\
\hline $\mathrm{Cu}(\mathrm{mg} / \mathrm{l})$ & 36.393 & 11.889 & 41.366 & 16.026 & 39.876 & 15.253 \\
\hline $\mathrm{Pb}(\mathrm{mg} / \mathrm{l})$ & 26.334 & 1.505 & 26.393 & 1.515 & 26.193 & 1.411 \\
\hline $\mathrm{Hg}(\mathrm{mg} / \mathrm{l})$ & 150.277 & 75.408 & & & 159.074 & 82.589 \\
\hline $\mathrm{Cd}(\mathrm{mg} / \mathrm{l})$ & 2.104 & 1.055 & & & & \\
\hline
\end{tabular}




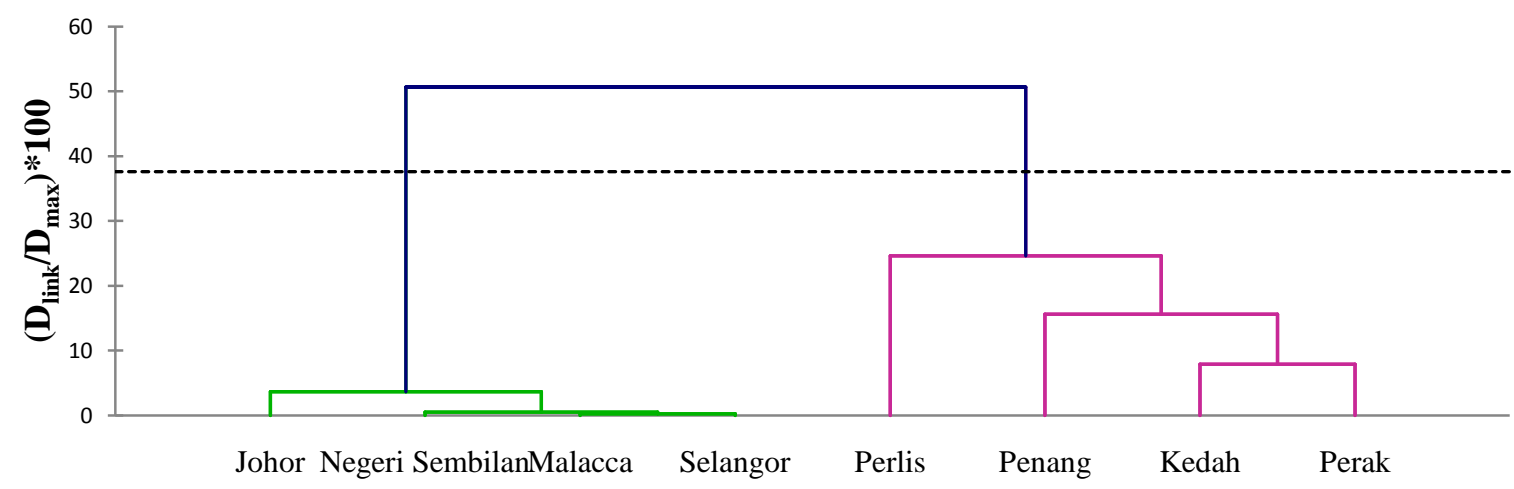

Figure 3.: (a) Dendrogram showing spatial clustering of heavy metals distribution along the Straits of Malacca
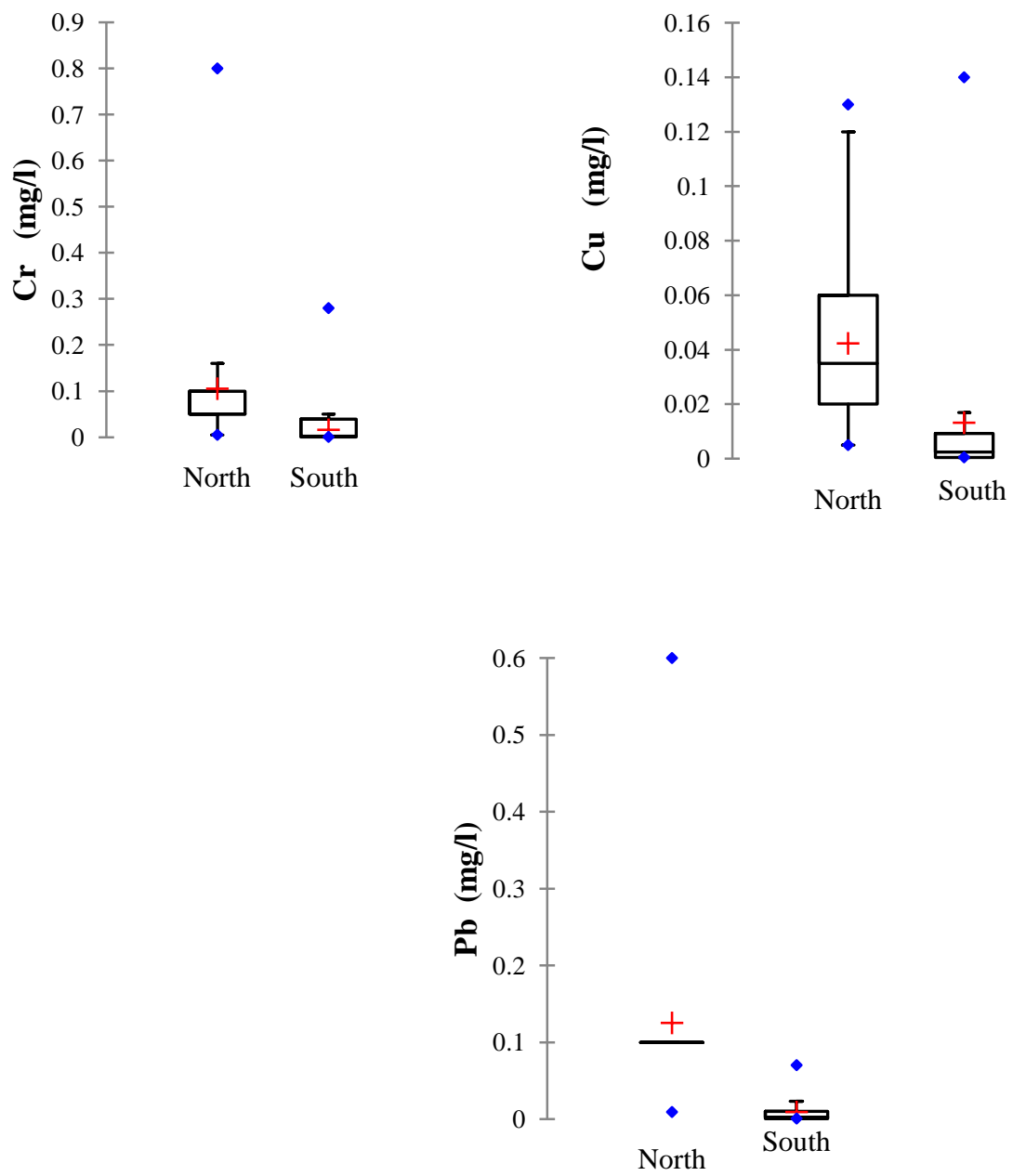

(b) Box and whisker plots showing the most significant variation of heavy metals along the Straits of Malacca obtained via forward stepwise DA 

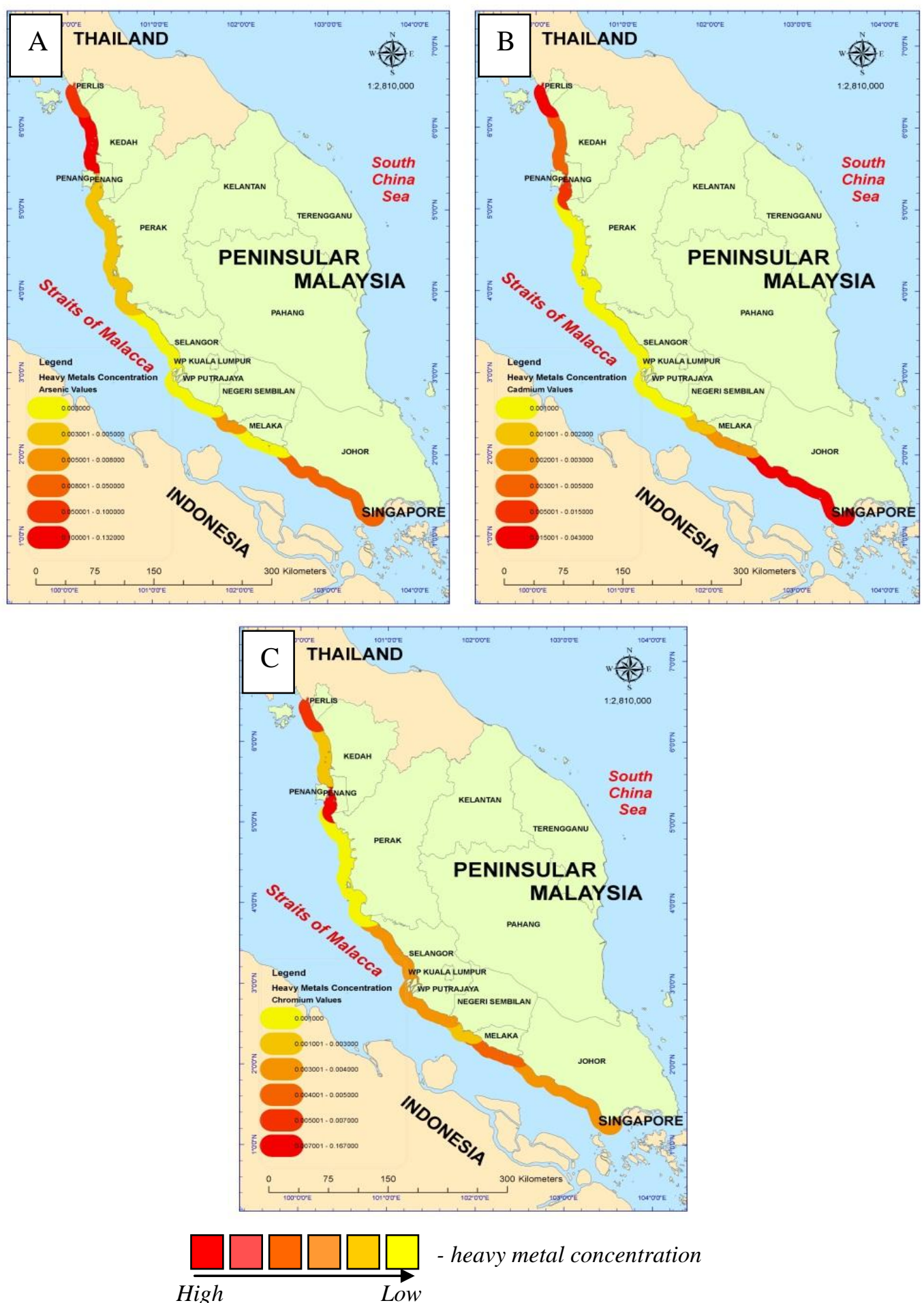

- heavy metal concentration

(c) Maps showing the distribution of (A) As, (B) Cd, and (C) Cr along the Straits of Malacca.

\subsection{Identification the possible variation sources of heavy metals contamination along the Straits of Malacca}

In this study, PCA was performed to further explore the identification of the most statistically significant sources that influence the contamination of heavy metals along the monitoring areas (northern and southern regions). Only PCs with eigenvalues $>1$ were considered as crucial. PCA reveals that there are three (3) factors found in the northern region that are responsible for $57.62 \%$ of the total heavy metal variation along the Straits of Malacca. PCA also revealed two (2) factors in the 
southern region which are responsible for $59.43 \%$ of the total variation along the Straits of Malacca. PCA results with variable loadings, variance and VFs are presented in Table 5.

Table 5: Loadings of measured variables in North and South regions along the Straits of Malacca

\begin{tabular}{llllll}
\hline \multirow{2}{*}{ Parameters } & \multicolumn{3}{c}{ North } & & \multicolumn{2}{l}{ South } \\
\cline { 2 - 6 } & VF1 & VF2 & VF3 & VF1 & VF2 \\
\hline $\mathrm{As}(\mathrm{mg} / \mathrm{l})$ & 0.386 & -0.096 & -0.196 & 0.125 & 0.813 \\
$\mathrm{Cr}(\mathrm{mg} / \mathrm{l})$ & 0.653 & -0.408 & -0.178 & 0.826 & -0.065 \\
$\mathrm{Cu}(\mathrm{mg} / \mathrm{l})$ & 0.730 & 0.278 & 0.076 & 0.817 & 0.134 \\
$\mathrm{~Pb}(\mathrm{mg} / \mathrm{l})$ & 0.041 & 0.879 & -0.091 & -0.450 & 0.550 \\
$\mathrm{Hg}(\mathrm{mg} / \mathrm{l})$ & 0.414 & 0.237 & 0.522 & -0.130 & -0.415 \\
$\mathrm{Cd}(\mathrm{mg} / \mathrm{l})$ & -0.079 & -0.131 & 0.845 & 0.906 & 0.013 \\
Eigenvalue & 1.300 & 1.122 & 1.036 & 2.407 & 1.159 \\
$\%$ Total variance & 21.662 & 18.702 & 17.258 & 40.118 & 19.313 \\
Cumulative Total variance & 21.662 & 40.364 & 57.622 & 40.118 & 59.430 \\
\hline
\end{tabular}

Varimax Factor (VF1) in the northern region reveals a total variance of $21.66 \%$ and is moderately loaded positively with $\mathrm{Cu}$ and $\mathrm{Cr}$. These metals are generated from anthropogenic activities and natural sources (Abdullah, A.R. et al., 1999) mostly from chemical weathering process at ports and shipping activities. Operational discharges of shipping activities such as cleaning of cargo residues and spilled oil are possible contributors to the pollution. Besides, coal combustion and chemical manufacturing are also contributors to the contamination. According to Shazili et al., 2006, $\mathrm{Cu}$ is generated as a result of mining activities in the State of Perak. The high concentration of $\mathrm{Cu}$ was found in Juru River, Pulau Pinang which flows directly into the Straits. In addition, Cu pollution loading in the marine water of the Straits is also a result from industrial activities located in the Juru Industrial Area as well as wastewater discharge from the existing sewage treatment plant adjacent to the Juru River (Idriss and Ahmad, 2012). $\mathrm{Cr}$ and $\mathrm{Cu}$ may also originate from tin mining activities and sand dredging operations as $\mathrm{Cr}$ can be found as ores in combination with other elements. Copper for instance may originate from the weathering of minerals such as malachite, cuprite, bornite, azurite, and chalcopyrite.

VF2 is responsible for $18.70 \%$ of the total heavy metal variation and a substantial amount of $\mathrm{Pb}$ is loaded into the Straits. Over $70 \%$ of $\mathrm{Pb}$ contamination into Straits results from anthropogenic activities (Yap et al., 2003). These can be attributed to various port activities such as extend use of anti-fouling paint on ships. Another source of contamination of $\mathrm{Pb}$ into Straits comes from the industrial areas of Juru, Pulau Pinang and the wastewater discharge from the nearby wastewater treatment plant (Shazili et al., 2006). Residual $\mathrm{Pb}$ persisting in the environment after years of usage of lead based petroleum products may still contribute the lead pollution. In addition, $\mathrm{Pb}$ can also result from the natural weathering effects of geochemical fractions (Yap et al., 2011).

In the third group, VF3 with a total variance of $17.26 \%$ is responsible for the positive loadings of $\mathrm{Hg}$ and $\mathrm{Cd}$ into the Straits. Point sources from land-based industrial effluents such as fertilizer manufacturing (Rezai et al., 2003) contributes heavily to the presence of $\mathrm{Hg}$. Cd pollution is mainly attributed to electronic products such as batteries (nickel-cadmium) and the State of Pulau Pinang is known to be the largest hub of electronics and semiconductor manufacturers (Malaysia National Report, 2002) in Peninsular Malaysia, hence there is certainly a huge possibility that Cd contamination results from activities related to this industry. Land-based activities such as mining and shipping (Nazli et al.,2010) are also known to be contributors to the release of $\mathrm{Cd}$ into the marine environment.

In the southern region, the same pattern of VF1 contributed for a total variance of $40.12 \%$, loaded with high-level concentrations of $\mathrm{Cr}, \mathrm{Cu}$ and $\mathrm{Cd}$. These metals dominate this group with strong 
positive loadings of $0.826,0.817$ and 0.906 respectively. The metals are produced mainly from anthropogenic sources either as land-based or sea-based pollutants (Yap et al., 2002; 2003; 2011; Shazili et al., 2006; Nazli et al., 2010; Todd et al., 2010). Langat River is highly contaminated with Cd as reported by Shazili (2006). However, Cai et al., 2012 reported that only Cd is from anthropogenic activities such as agriculture, while both $\mathrm{Cr}$ and $\mathrm{Cu}$ are from natural sources. On the contrary, in Malacca, $\mathrm{Cu}$ is reported to mainly originate from the Alor Gajah Industrial Estate (National Report, 2002). Shazili et al.(2006) reported that $\mathrm{Cu}$ also results from agricultural activities related to pig farming and is ubiquitous along the mangrove areas of Sepang (Selangor) and Lukut (Negeri Sembilan).

VF2 responsible for a total variance of $19.31 \%$, contributing moderate and strong loadings of As and $\mathrm{Pb}$ into the Straits. As is thought to originate mainly from agricultural sectors (Cai et al., 2012) as it is mostly linked to pesticides and timber preservation. Although lead based petroleum products are no longer in use, residuals of lead from years of usage of leaded petrol may still be a strong contributor to $\mathrm{Pb}$ pollution today (Todd et al., 2010). High concentration of $\mathrm{Pb}$ is still found in the State of Johor (Shazili et. al., 2006). Agricultural activities associated with Pb contamination in marine environment are usually due to effluents from pig farms (Moral et al., 2008). Urbanization and industrialization (such as petroleum production and metal smelting), are identified to be the main contributors to the increase of both metal concentrations. The level of concentration of As in this study was not statistically significant as a contributor to heavy metals in the northern region. The As is mainly derived from the emission of fossil fuel from petroleum refineries, which are unavailable in the northern region. On the contrary, $\mathrm{Hg}$ is the most insignificant source of pollution in the southern region.

\section{CONCLUSION}

This study has shown that based on the data collected on heavy metals along the Straits of Malacca, pollution caused by these metals is worrying. PCA reveals that there are three (3) factors found in the northern region that are responsible for $57.62 \%$ of the total heavy metal variation along the Straits of Malacca and two (2) factors in the southern region which are responsible for $59.43 \%$ of the total variation. Further analyses reveal that in the southern region, $\mathrm{Cr}, \mathrm{Cu}$ and $\mathrm{Cd}$ are mainly responsible for the varimax factor total variance of $40.12 \%$. In the northern region, only $\mathrm{Cu}$ and $\mathrm{Cr}$ contribute significantly ( $\mathrm{VF} \sim 21.66 \%$ ). These heavy metal pollutants can be attributed to various anthropogenic activities related to the industry as well as port and shipping activities. Nevertheless, natural weathering process may also play a role as a source of these heavy metals. From the application of various chemometric tools, it is observed that the monitoring of heavy metals can be optimally performed via a single state, each representing the northern and southern region. This would save time and reduce the cost of monitoring. Consequently, a time saving, cost effective regime of heavy metal monitoring based on the finding of this study should be designed by the relevant authorities to ensure continuous observation of these pollutants.

\section{Acknowledgements}

The Authors are thankful to East Coast Environmental Research Institute (ESERI), UNISZA, Department of Environment (DOE) Malaysia, Department of Chemistry Malaysia, Department of Chemistry, Malaya University and the reviewers for their assistance and valuable comments.

\section{REFERENCES}

Abdullah, A. R., Tahir, N. M., Loong, T. S., Hoque, T. M., \& Sulaiman, A. H. (1999). The GEF/UNDP/IMO Malacca Straits demonstration project: Sources of pollution. Marine Pollution Bulletin, 39(1-12), 229-233. 
Alba, M. D., Galindo-Riano, M. D., Casanueva-Marenco, M. J., Garcia-Vargas, M. \& Kosore, C.M., (2011). Assessment of the metal pollution, potential toxicity and speciation of sediment from Algeciras Bay (South of Spain) using chemometric tools. Journal Of Hazardous Materials. 190: 177-187.

Aquadrone, S., Prearo, M., Brizio, P., Gavenilli, S.,Pellagrino, M.,Scanzio, T.,Guarize, S.,Benedetto, A., \& Abette, M.C. (2013). Heavy Metal Distribution in muscle, liver, kidney and gill of European catfish (silurus glanis) from Italian Rivers. Chemosphere. 90(2):358 - 365.

Blundell, a., Hannam, J. a., Dearing, J. a., \& Boyle, J. F. (2009). Detecting atmospheric pollution in surface soils using magnetic measurements: A reappraisal using an England and Wales database. Environmental Pollution, 157(10), 2878-2890.

Cai, L., Xu, Z., Ren, M. Guo, Q., Hu, X., Hu, G., Wan, H. \& Peng, P., (2012). Source identification of eight hazardous heavy metals in agricultural soils of Huizhou, Guangdong Province, China. Ecotoxicology and Environmental Safety. 78: 2-8.

DOE (2008). Environmental Quality Report (2008) - Marine and Island Marine Quality. Putrajaya: DOE Malaysia.

Dominick, D., Juahir, H., Latif, M. T., Zain, S. M., \& Aris, A. Z. (2012). Spatial assessment of air quality patterns in Malaysia using multivariate analysis. Atmospheric Environment. 60: 172-181.

Fermo, P., Beretta, G., Facino, R. M., Gelmini, F., \& Piazzalunga, A. (2013). Ionic profile of honey as a potential indicator of botanical origin and global environmental pollution. Environmental Pollution, 178, 173-181.

Grande, J.A., Borrego, J., Morales, J.A. \& De La Torre, M.L. (2003). A description of how metal pollution occurs in the Tinto-Odiel rias (Huelva-Spain) through the application of cluster analysis. Marine Pollution Bulletin. 46: 475-480.

Golovanova, I. L. (2008) Effects of heavy metals on the physiological and biochemical status of fishes and aquatic invertebrates. Inland Water Biology. 1: 93-101.

Irwandi, J. \& Farida, O., (2009). Mineral and heavy metal contents of marine fin fish in Langkawi Island, Malaysia. International Food Research Journal. 16: 105-112.

Idriss, A.A. and Ahmad, A.K. (2012). Concentration of Selection of Heavy Metals in Water of Juru River in Penang, Malaysia. African Journal of Biotechnology 11(33): 8234-8240.

Juahir, H., Zain, S. M., Yusoff, M. K., Hanidza, T. I. T., Armi, A. S. M., Toriman, M. E. \& Mokhtar, M., (2011). Spatial water quality assessment of Langat River Basin (Malaysia) using environmetric techniques. Environ. Monit. Assess. 173: 625-641.

Junninen, H., Niska, H., Tuppurainen, K., \& Ruuskanen, J. (2004). Methods for imputation of missing values in air quality data sets, 38, 2895-2907.

Kannel, P. R., Lee, S., Kanel, S. R. \& Khan, S. P., (2007), Chemometric application in classification and assessment of monitoring locations of an urban river system. Analytical Chimica Acta.. 582: 390-399. 
Kano, M., Hasebe, S., Hashimoto, I., \& Ohno H. (2001), A new multivariate statistical process monitoring method using principal component analysis. Computer and Chemical engineering . 25: 1103-1113.

Liow, L.H., Sodhi, N.S. \& Elmqvist, T. (2001). Bee Diversity along a disturbance gradient in tropical land low forest of Southeast Asia. Journal of Applied Ecology. 38(1):180-192.

Moral,R., Perez-Mucinia, M.D,Perez-Espinosa,A., Moreno-Casselles,J.,Paredes, J., \& Rufete, B. (2008). Salinity, organic content, micronutrients and heavy metals in pig slurries from South Eastern Spain. Waste Management. 28(2):367-381.

Nazli, M. F. \& Hashim, N. R., (2010). Heavy Metal Concentrations in an Important Mangrove Species, Sonneratia caseolaris, in Peninsular Malaysia. Environment Asia (Special issue).1: 5055.

Retnam, A., Zakaria, M. P., Juahir, H., Aris, A. Z., Zali, M. A., \& Kasim, M. F. (2013). Chemometric techniques in distribution, characterisation and source apportionment of polycyclic aromatic hydrocarbons (PAHS) in aquaculture sediments in Malaysia. Marine Pollution Bulletin, 69 (1-2): $55-66$.

Rezai, H., Yusoff, F. M. \& Yap, C. K., (2003). Mercury in zooplankton from the Malacca Straits. Indian Journal of Marine Sciences. 32(3): 240-243

Rusdi, MHBM. (2012). Protecting vital sea lines of communication: A study of the proposed designation of the Straits of Malacca and Singapore as a particularly sensitive sea area. Ocean \& Coastal Management. 57: 79-94.

Satheeshkumar, P. \& Khan, A. B., (2011). Identification of mangrove water quality by multivariate statistical analysis methods in Pondicherry coast, India. Environ. Monit. Assess. 184 (6): 3761-3774.

Santos-Echeandía, J., Prego, R. \& Cobelo-García, A. (2009). Intra-annual variation and baseline concentrations of dissolved trace metals in the Vigo Ria and adjacent coastal waters (NE Atlantic Coast). Marine Pollution Bulletin. 58(2): 298-303.

Shazili, N. A. M., Yunus, K., Ahmad, A. S., Abdullah, N. \& Rashid, M. K. A., (2006). Heavy metal pollution status in the Malaysian aquatic environment. Aquatic Ecosystem Health \& Management. 9(2): 137-145.

Singh, K. P., Malik, A., Mohan, D. \& Sinha, S., (2004) Multivariate statistical techniques for the evaluation of spatial and temporal variations in water quality of Gomti River (India). Water Research. 38: 3890-3992.

Sun, J., Wang, M.H. \& Ho, Y.S. (2012), A historical review and bibliometric analysis of research on estuary pollution. Marine Pollution Bulletin. 64(1):13-21.

Thia-Eng, C., Gorre, I. R. L., Ross, S. A., Bernad, S. R., Gervacio, B. \& Ebarvia, M. C. (2000). The Malacca Straits. Marine Pollution Bulletin. 41: 160-178.

Todd, P. A., Ong, X. \& Chou, L. M. (2010). Impacts of pollution on marine life in Southeast Asia. Biodivers. Conserve. 19: 1063-1082. 
Tokahogu, S. \& Kartal, S. (2006). Multivariate analysis of the data and speciation of heavy metals in street dust samples from the Organized Industrial District in Kayseri (Turkey). Atmospheric Environment. 40: 2797-2805.

UNEP(2002). National Report of Malaysia - Formulation of a Transboundary Diagnostic Analysis And Preliminary Framework of a Strategic Action Programme for the Bay of Bengal,.pp 15-25.

Wood, AKH., Ahmad, Z., Shazili, NAM. \& Yaacob, R. (1997). Geochemistry of Sediments in Johor Straits between Malaysia and Singapore. Elsevier

Xue, J., Lee, C., Wakeham, S.G. \& Armstrong, R. A. (2011). Using principal components analysis (PCA) with cluster analysis to study the organic geochemistry of sinking particles in the ocean. Organic Geovhemistry. 42: 356-367.

Yap, C. K., Ismail, A., Tan., S. G. \& Omar, H., (2002). Correlations between speciation of Cd, Cu, Pb and $\mathrm{Zn}$ in sediment and their concentrations in total soft tissue of green-lipped mussel Pernaviridis from the west coast of Peninsular Malaysia. Environment International. 28: 117-126

Yap, C. K., Ismail, A. \& Tan., S. G., (2003). Cd and Zn concentrations in the straits of Malacca and intertidal sediments of the west coast of Peninsular Malaysia. Marine Pollution Bulletin. 46: 13411358.

Yap, C. K., Ismail, A. \& Tan., S. G., (2003). Lead in Surface Sediments of the Straits of Malacca . Indian Journal of Marine Sciences. 32(4): 323-328.

Yap, C. K. \& Pang, B. H., (2011) Assessment of Cu, Pb, and $\mathrm{Zn}$ contamination in sediment of north western Peninsular Malaysia by using sediment quality values and different geochemical indices. Environment Monitoring Assessment. 183: 23-39.

Yap, C. K.., Azmizan, A. R. \& Hanif, M. S., (2011). Biomonitoring of Trace Metals (Fe, Cu, and Ni) in the Mangrove Area of Peninsular Malaysia Using Different Soft Tissues of Flat Tree Oyster Isognomon alatus. Water, Air, Soil Pollut. 218: 19-36.

Zhou, F., Guo, H., Liu, Y. \& Jiang, Y., (2007). Chemometrics data analysis of marine water quality and source identification in Southern Hong Kong. Marine Pollution Bulletin. 54: 745-756. 